\title{
13 The Influence of Psychological Contracts on Decision-Making in Whistleblowing Processes
}

\author{
Åse Storhang Hole and Therese E. Sverdrup
}

\section{Introduction}

Recent decades of research have considerably broadened our understanding of whistleblowing. To date, most of the focus has been on the whistleblowers themselves: what makes them report, what and how they report, and what happens to them after they've blown the whistle (Lewis, Brown, \& Moberly, 2014). But we think it no less important to focus on non-reporting behavior because most employees stand by in silence (Olsen, 2014). They may do so out of fear of retaliation, lack of trust in managers or other recipients of the concerns, a belief that nothing can or will be done about the problems, uncertainty about the seriousness and evidence of the wrongdoing, or a sense that others simply don't see the problem as they do (Near, Rehg, Van Scotter, \& Miceli, 2004). Another possible explanation for non-reporting, as we're about to demonstrate, may lie with close relationships between employee and employer, or between colleagues, reinforced by unwritten expectations about mutual loyalty. This chapter is about the effect of psychological contracts on whistleblowing.

The particular whistleblowing incident we are studying here occurred in a small Norwegian town, where close relationships are common, and colleagues are more tightly connected and dependent on one another than is usual in a larger society. As described by Peer Jacob Svenkerud (PJS), the whistleblower in this story, unwritten expectations permeated his company Norsk Tipping (NT). Employees enjoyed an interesting, well-paid job in one of the most prestigious firms in the region. Through the whistleblower's story, we learn about some of these unwritten expectations. For example, if media raised critical questions about NT, PJS was expected to defend its image and redirect the reporters' attention. Also, questionable practices were passed over at the weekly top-executive meetings. And employees seemed expected to promote NT's popular image of being a joyous workplace.

Expectations like these led to the following question in the introduction of the whistleblower's story in Chapter 1: "What happens to the decisionmaking processes in a company when critical voices are suppressed?" 


\section{Psychological Contracts}

The psychological contract is a concept that addresses unwritten expectations. It refers to the employees' perceptions about the reciprocal relationship with their employer (Rousseau, 1989). Mutual obligations are the essence of any employment contract, of course, as they define the relationship between employee and employer. Obligations, or beliefs, are what the employee expects to receive in return for loyalty, work effort, and commitment. The employer, meanwhile, has expectations of employees in return for wages and good working conditions. These expectations come from either implicit or explicit promises of future exchange or reciprocity, and constitute the psychological contracts between employer and employee- and between colleagues, too.

Research into psychological contracts, and especially their violation, shows that unwritten agreements and expectations between employers and employees greatly impact organizational behavior (Rousseau, 1989; Robinson \& Rousseau, 1994). Psychological contracts are individual and perceptual and can be transactional, relational, and ideological. Transactional contracts are short term and characterized by less involvement of the parties. Relational contracts are long term and characterized by mutual loyalty and trust (Rousseau, 1995). Ideological contracts are value based and involve working for a higher cause or ideology (Thompson \& Bunderson, 2003).

Fear of violating one or more of these contracts might well prohibit, or at least inhibit, whistleblowing. When unethical behavior occurs at the workplace, close relationships and strong mutual psychological contracts might hinder the reporting of wrongdoing, especially if the contracts are tight and mean a lot to the parties, as we find in the present case. Supervisors and colleagues alike react negatively toward the whistleblower because they consider whistleblowing a breach of a psychological contract, a violation of the unwritten expectations and beliefs about mutual agreements.

But here's a classic dilemma: What do you do if a close friend or colleague has engaged in issues that you consider unethical? And what if the wrongdoer is your own supervisor? By the same token, how does the wrongdoer react toward the whistleblower when he is a close colleague? Psychological contracts can cloud the judgments and reactions of all parties-the observers, the whistleblower, the wrongdoer, and the recipients of the concerns. Psychological contract theory may help our understanding of the outcomes of several stages of the whistleblowing process.

Our aim in this chapter is to show how psychological contract theory can explain the steps taken in the whistleblowing process-the fraught decision to blow the whistle, the receiver of the concern, and the reactions to the whistleblower. In the following section, we discuss the concept of whistleblowing, whistleblowing effectiveness, and the typical stages of a whistleblowing process. 


\section{The Concept of Whistleblowing}

A standard definition of whistleblowing is "the disclosure by organization members (former or current) of illegal, immoral, or illegitimate practices under the control of their employers, to persons or organizations that may be able to effect action" (Near \& Miceli, 1985, p. 4). Note that this definition excludes persons outside the organization. According to Miceli, Dreyfus, \& Near (2014), it's important to distinguish between whistleblowing behavior and other, external forms of disclosing of organizational wrongdoing. They call the latter "bell-ringing," which means the reporting of organizational wrongdoing by outsiders.

To distinguish normal reporting from whistleblowing, Skivenes and Trygstad (2014) introduced the classification of weak and strong whistleblowing, where weak whistleblowing involves reporting to your nearest manager, whereas strong whistleblowing refers to cases in which the employee then continues to report via other channels after seeing no improvement. Miethe (1999) argued that a broad definition of whistleblowing is important to encourage reporting of all kinds of concerns. Miceli and Near (2013) argued that although there are similarities between organizational voice behavior (i.e., constructive challenge to the status quo with the intent of improving the situation rather than merely criticizing) and whistleblowing, there are also differences. Matters that trigger voice and whistleblowing are not the same, because whistleblowing is a reaction to wrongdoing, while voice includes all kinds of concerns. Whereas voice often involves "friendly suggestions," whistleblowing questions managers' authority and ethical judgments.

Whistleblowing is generally viewed positively as a prosocial behavior (Miceli, Near, Rehg, \& Van Scotter, 2012; Miceli, Near, \& Dworkin, 2008; Dozier \& Miceli, 1985). People who blow the whistle are doing so in an attempt to correct wrongdoing. Prosocial behavior can include both selfish (egoistic) and unselfish (altruistic) motives on the part of the actor (Dozier \& Miceli, 1985). It is important to note, however, that while the motives of the whistleblower can be egoistic, he or she might help address important issues for the organization.

Our discussion in this chapter includes only whistleblowers who are former or present members of an organization. Another important distinction is that the recipient must be someone who's in a position to correct the wrongdoing. We consider all kinds of reporting of wrongdoing to be important and therefore prefer the broad definition of the concept.

\section{The Whistleblowing Process}

Whistleblowing is a complex process consisting of several stages, starting with observation of the wrongdoing and the decision of the observer 


\section{8 Åse Storhang Hole and Therese E. Sverdrup}

whether to blow the whistle, either through internal or external channels. Further stages of the process are the receiving of the concern, including the decisions and reactions of the recipient. Still later stages of the process account for if, and in what ways, the problems are resolved (Near \& Miceli, 1995). Finally, in an ideal situation, the process is evaluated and steps are taken to learn how to treat similar situations, problems, and concerns (NOU, 2018:6) (Figure 13.1).

The outcomes of each step in a whistleblowing process depend on both individual and situational factors concerning the issue at stake-for example, the power and position of the whistleblower, the wrongdoer, and the recipient of the concern (Near \& Miceli, 1995). Our focus here is to study the influence of the psychological contracts at several stages of the process through the lens of psychological contract theory. We propose that violation of psychological contracts, or fear of it, has influenced the development of this whistleblowing process at the six first stages in Figure 13.1.

Whistleblowing effectiveness may be defined as "the extent to which the questionable or wrongful practice (or omission) is terminated at least partly because of whistleblowing and within a reasonable time frame" (Near \& Miceli, 1995, p. 681). Outcomes of the different stages of a

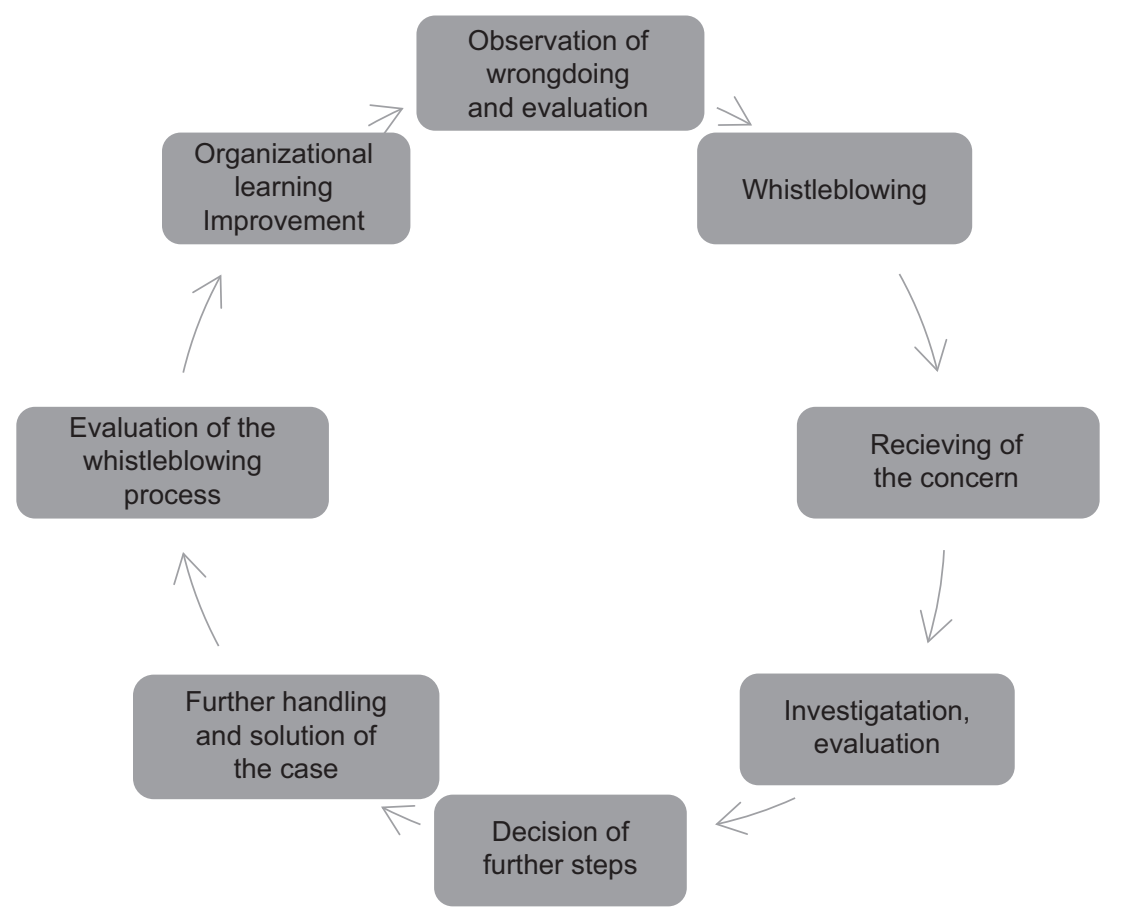

Figure 13.1 The Whistleblowing Process (based on Frøstrup et al. 2018, p. 137). 
whistleblowing process will influence the development of the total process and the whistleblowing effectiveness.

In the following section, we address the concept of the psychological contract and discuss different versions of it, which will lay the foundation for applying that perspective to the whistleblowing process in the present case.

\section{Psychological Contract Theory}

A psychological contract contains the individual's perceptions about the reciprocal relationship with their employer (Rousseau \& Tijoriwala, 1998). In a psychological contract, the employer and employee are engaged in a contractual relationship in which both parties feel they owe each other something. This "something" can refer to training, promotion, recognition, trust, fair pay, and a good working environment. An important part of the contract is that in exchange for good work the employee will expect something in return, such as further training or a promotion. Thus, a psychological contract implies that there is a reciprocal relationship between the parties. The premise is that without the promise of a future exchange, neither party has incentives to contribute much of anything to the other, which may result in a strain or termination of the relationship (Robinson \& Rousseau, 1994).

Most research on psychological contracts has focused on the consequences of contract breaches and has found connections to many work-related outcomes-for example, job satisfaction, organizational commitment, turnover intention, in-role performance, and organizational citizenship behavior (Zhao, Wayne, Glibkowski, \& Bravo, 2007). Also, a stream of research has been carried out on outcomes of psychological contract breach that can be labeled negative behavior (Turnley \& Feldman, 1999). Specifically, these studies suggest that when employees experience a psychological contract breach, they engage in counter-productive work behavior and strike back at the employer in various ways, such as via abuse, production deviance, sabotage, theft, and withdrawal (Bordia, Restubog, \& Tang, 2008; Restubog, Bordia, \& Tang, 2007; Jensen, Opland, \& Ryan, 2010). Thus, the consequences of breaching a psychological contract are substantial, meaning that handling breaches and knowing the content of the psychological contract (what exactly was breached) are important to prevent these negative consequences.

Research on the substance of the psychological contract shows that there are several different types that we enumerate here (Rousseau, 1990). A transactional contract is composed of specific, short-term obligations entailing limited involvement of the parties, as for a seasoned worker, who exchanges money for work (tit-for-tat). A relational contract entails broad, open-ended, long-term obligations and is based on mutual trust and loyalty (Morrison \& Robinson, 1997; 229)—for example, the permanent 
worker who exchanges lifetime work for loyalty to the company. According to Rousseau (2004), employees with a relational contract tend to put more effort into their job, help colleagues, and support changes in the organization. A value-based or ideological contract involves working for a higher cause or ideology and fulfilling expectations toward an overarching goal of the organization (Thompson \& Bunderson, 2003). Employees with such a contract have been shown to exert more extrarole behavior (Vantilborgh et al., 2014)—for example, a worker who is willing to work harder not only for money, but for a higher cause as well, such as working for a medical company that helps save lives, or a fertilizer company that helps feed the world. Normative contracts occur when several people agree on terms in their individual psychological contracts (Rousseau, 1995). When co-workers agree among themselves on the terms of their individual psychological contract with the employer, the agreement becomes a normative contract. Normative contracts are products of social integration, discussion, and interpretation, creating similarity in the way people see their organization and their relationship to it. A horizontal contract occurs among colleagues (Seeck \& Parzefall, 2008; Sverdrup, 2012; Sverdrup \& Schei, 2015). The exchanges and obligations are mostly concerned with the task that they work on-making an effort, delivering good quality - and with their mutual relationship, recognition, friendship, and generosity (Sverdrup, 2012). Contracts among colleagues can be evaluated not only through the content of the exchange, but also by the feature of constriction (tight vs. loose). That is, in some cases colleagues develop tight psychological contracts, meaning that you can trust that the other person will deliver to your expectations and be able to explicitly state those expectations (Sverdrup, 2014). Loose psychological contracts, by definition, have more breaches and more implicit expectations among colleagues. Thus, the content (task vs. relational) and type (tight vs. loose) of psychological contract have some implications for how colleagues act toward one another.

These different types of contracts hint at the relationships that are involved when whistleblowing occurs within the organization.

\section{Research Linking Whistleblowing and Psychological Contract Theory}

The relationship between psychological contracts and whistleblowing can be understood in two all-encompassing ways. On the one hand, violations of psychological contracts might lead an employee to blow the whistle because of a perception of harm and unfair treatment that amounts to a violation (Turnley \& Feldman, 1999). This is supported by Gundlach, Martinko, and Douglas (2008), who show that anger and disappointment after psychological contract breaches can result in whistleblowing. Furthermore, Vandekerckhove and Commers (2004) have 
argued that disrupting loyalty within psychological contracts can motivate one to blow the whistle.

On the other hand, a strong psychological contract, where both parties feel they owe each other loyalty, may inhibit whistleblowing. That is, close relationships can make it difficult both to recognize the wrongdoing and to report it (Miceli et al., 2008). For instance, the content of a psychological contract may be such that by blowing the whistle one violates the psychological contract of loyalty. This could also be the case with peers reporting. Yet, research on whistleblowing has focused primarily on reporting the wrongdoing of superiors rather than the wrongdoing of peers. Trevino and Victor (1992) studied peers reporting as a specific kind of whistleblowing behavior. Reporting a peer's wrongdoing to higher authorities may be more difficult than reporting a superior because of group norms against reporting peers' misconduct (Greenberger, Miceli, \& Cohen, 1987) and because of stronger identification and empathy with peers (Randall \& Gibson, 1991). Thus, a tight psychological contract among peers about not reporting one another's wrongdoing-we're all in this together-may lead to less whistleblowing.

Lewis (2011) suggested that whistleblowing should be regarded as an act of loyalty. Companies should develop psychological contracts that promote a culture of trust and openness. Such contracts might support and promote whistleblowing. Gundlach et al. (2008) stated that new understanding of the whistleblowing process could be gained by applying the psychological contract perspective and suggested that future research should examine the connection between the psychological contract and whistleblowing,

We hope that our analysis of this particular whistleblowing process can clarify the link between whistleblowing and the psychological contract. In the following section, we analyze some critical incidents of PJS's whistleblowing story, where we demonstrate how the psychological contract perspective sheds light on the decision-making of the central actors.

\section{Analyzing the Whistleblowing Process Through the Psychological Contract Perspective}

In the following discussion of PJS's narrative, we analyze the critical incidents following his observation of questionable practices. We trace his whistleblowing process in three steps: (1) blowing the whistle, (2) choosing to go public, and (3) choosing to resign. By applying the psychological contract perspective, we can better understand the dilemmas that a whistleblower faces when choosing to blow the whistle and dealing with the blowback. We use the narratives of PJS to show how psychological contracts with central actors such as the CEO, colleagues, and the chairman of the board (COB) influenced PJS's decisions along the way. We 


\section{2 Åse Storhang Hole and Therese E. Sverdrup}

also reference newspaper articles, the audit report, and NT's own annual reports to supplement the data from the narrative.

\section{Blowing the Whistle}

In the situation leading up to PJS's blowing the whistle to the COB, we find that the psychological contract played out both vertically and horizontally. PJS sensed what was expected through his hiring process and the first meetings. NT was one of the most attractive and prestigious companies in the region and had since 1948 been a vital source of funding for amateur Norwegian sports activities (Annual Report, 2017). The annual reports consistently state that the company's goals are to make people happy, give their dreams a chance every day, and support good social causes. Thus, by working at NT, employees enjoy a feeling of contributing to society. This is a value-based contract, where one works for a higher cause or ideology, and fulfills expectations toward an overarching goal of the organization (Thompson \& Bunderson, 2003). Hence, NT employees probably anticipate an ideological contract with the company. As PJS expressed it: "[NT] had a very good reputation. Everybody wanted to work here. I was flattered to have gotten the job. The turnover was virtually non-existent. People came and they stayed there throughout their lives."

One advantage of an ideological psychological contract is the feeling of loyalty it imparts toward the company's culture and its mission, making it difficult for people to think that anything can go wrong in a company with such a long and proud tradition. Hence, employees at NT had sound reasons for being in good faith when working in a company with idealistic values and visions. The fact that NT was state owned and a non-profit also strengthened the impression of it as value based.

When PJS started to work as the Senior Vice President Information and External Relations, he tells us that he soon began to worry about issues such as the huge budgets, the lack of a transparent budget process, and also the lack of corporate strategies concerning corporate social responsibility (CSR). These worries jolted him enough that he might have interpreted them as constituting an ideological contract breach, which may have initially triggered thoughts of reporting or whistleblowing (Gundlach et al., 2008). Countering that impulse, though, was his strong relational contract of being loyal to the company and the CEO, which also carried with it the condition that you don't question corporate policies and procedures. As PJS put it, "an internal understanding was that if you asked too many questions, it will have a consequence." Further, the company's employee benefits were excellent, thus leading to strong transactional contracts. Again, as PJS put it: "You should really be glad that you're getting an opportunity to work here and that you have a good salary. You should embrace the benefits you have, not challenge 
the benefits that people have." So here was his dilemma: Should he act on the violation of the ideological contract and report the irregularities, or should he honor his strong relational and transactional contract and stay silent?

A boat trip with a friend was a tipping point for his decision. That friend was also a respected colleague, so his friendship resembled a tight and relational horizontal contract. This seems to have reinforced PJS's choice to blow the whistle. When doing so, he presented a list of irregularities to the $\mathrm{COB}$, who both promised to protect him and encouraged him to remain in the company. In PJS's words, the COB said, "Work as you normally do, and trust me when I say that I will protect you." This promise shows how a psychological contract between the two men developed. But later, during the process of blowing the whistle to the board, PJS says he felt that his expectations of getting the COB's support were violated: "He kept his word about keeping it quiet, but he was never a visible supporter. He never called me to see how I was doing." PJS clearly expected visible support and care, and the $\mathrm{COB}$ violated that expectation. This shows how the psychological contract often is implicit, and if it is not mutual, it can have a strong influence on the feelings of the parties involved.

Although one of PJS's mentors had warned him that the COB and others on the board probably would try to downplay the case, they chose to violate their promises (the psychological contract) in a rank way. During the follow-up meeting, the $\mathrm{COB}$ asked if the whistleblower was satisfied with how management planned to handle the irregularities. They did not mention that they appreciated his openness and the fact that he had reported the wrongdoing. All they said was: "We'll come back to you. Is that good enough for you? Are you satisfied?"

Some colleagues of PJS had expressed concerns and raised critical questions themselves, but not openly. Instead, according to PJS, they had encouraged him to blow the whistle for them: "You have to do it!" Perhaps he had reason to believe that at least some of them would then give him visible support and stand by him, but no, he felt himself left standing alone, and nobody ever openly pledged to stand shoulder to shoulder with him. PJS might have viewed this as disloyalty, a breach of a psychological contract. But, to be fair to them, raising critical questions could mean violating a vertical contract of loyalty to the CEO and perhaps could cost them benefits, job safety, and well-being at the workplace (as outlined earlier).

PJS at last decided to blow the whistle, finally expecting that he would get at least some support. But, as already mentioned, he got none, at least not openly. Whistleblowing research shows that whistleblowers often experience collapsing support from managers and co-workers, and many of them feel lonely and isolated at the workplace. Many also suffer from retaliation (Trygstad, 2017; Bjørkelo, 2013; Near et al., 2004; Rehg, 


\section{4 Åse Storhaug Hole and Therese E. Sverdrup}

Miceli, Near, \& Van Scotter, 2008). Lack of support can be perceived as a breach of a relational contract among colleagues.

\section{Choosing to Go Public}

PJS remained in the company, still as an anonymous whistleblower, but felt lonely and guilty: "No one knew who had turned so many people's lives upside down." A new permanent CEO was hired in the fall of 2008, and, shortly after, a new COB replaced the one with whom PJS had negotiated the agreement. The audit general worked in the company for almost two years, which put a great strain on NT employees. The new leadership team had to focus on moving forward and getting business back to normal.

A dramatic turn of the whistleblowing process occurred in January 2010 when one of the biggest financial newspapers called PJS and informed him that they knew he was the whistleblower. PJS then insisted on coming forward, but the new permanent CEO hesitated and did not want him to do so. PJS probably saw this lack of support as a violation of a psychological contract and reacted with anger and frustration.

Similar reactions after a psychological contract violation are described in the literature (Sverdrup, 2012; Robinson \& Rousseau, 1994; Gundlach et al., 2008). In a meeting with all the company's managers, the top management's concern was how to repair NT's reputation and the future role of the whistleblower; little was said to support or praise PJS for courageously coming forward and reporting wrongdoing. Hence, because PJS at first was assured of support from the new CEO but then later was questioned about his future with the company, it looked to him like a strong contract breach. The rest of the managers chose to stand by the new CEO in silence, not supporting PJS. Nobody reassured him that he had done the right thing. As PJS says, "And that meeting was-as I see it- the start of my exit."

The tight psychological contract described by Sverdrup (2014) demonstrates how people might feel obligated to fulfill expectations to one another, as in "If I do something for you, you will do something for me." PJS states: "In a small city . . . everyone knows everyone. People that are recruited into higher positions are often part of the same network." Working with the same suppliers and companies in the business network for many years also created close ties: "We had some suppliers that we had had for years. It was a very personal relationship. They were friends." The narrative also describes close ties to the unions. We interpret this as strong horizontal contracts among the employees and possibly among the various external stakeholders, which explains why the whistleblowing was such a strain on so many people and relationships. Power distance matters in whistleblowing cases. Close relations make the process more difficult for the involved parties (Miceli et al., 2008). 
Summing up, the psychological contract breach between PJS and the new permanent CEO led to anger and frustration for PJS. The tight psychological contracts between the managers and external stakeholders prevented support for the actions taken by PJS and thus represented a breach of horizontal contracts.

\section{Choosing to Resign}

In the aftermath, when PJS's identity became known, many people shunned him. Although some colleagues had earlier supported him and encouraged him to voice concerns which they had themselves, they were silent in the aftermath. One colleague also expressed frustration. PJS's double role-blowing the whistle and remaining in the organization while keeping a secret-created frustration and anger among some colleagues in the top leadership group. As one of them said: "One thing might be that I do not agree with your assumptions and why you did what you did, but I certainly don't agree with you keeping this secret for this long." Colleagues had expected information, and by keeping the case a secret, PJS may have violated a psychological contract with them. PJS had also expected more support from external stakeholders, such as the Ministry of Culture, but they remained silent. The new permanent CEO and COB had promised their support, but gradually PJS realized that his time at the company was over: "They never called to ask how I was doing and seemed to care more about the people who were angry."

We have no data from the other parties in the process, but we have reason to believe that some of the leaders might have felt a breach of a psychological contract upon hearing that PJS had been hiding as a whistleblower. Tight psychological contracts had over time developed among the members of the top leadership group. This demonstrates how the psychological contract as a perspective allows for an understanding of both sides of the contract.

In the aftermath, the $\mathrm{COB}$ and others in top management were concerned with restoring NT's image and focused on normalizing the organization. The notes and objections in the audit reports had to be handled and corrected. Hence, the well-being of the whistleblower got less attention. For the whistleblower, this might be interpreted as a psychological contract breach.

\section{Discussion}

By applying the psychological contract perspective, we hope to have shed light on the complexity of a whistleblowing process with respect to the different parties involved, the dilemmas raised, and the reason the process unfolded as it did. Our analysis shows how psychological contracts both with respect to the contracts between the individual and the organization 


\section{6 Åse Storhaug Hole and Therese E. Sverdrup}

(ideological, relational, transactional), between the group and the organization (normative), and between individuals (horizontal—tight/loose) and whether or not these contracts were fulfilled or breached, can serve as one possible explanation of why the whistleblowing process proceeded as it did. We argue that all categories of contracts came into play throughout the whistleblowing process. Sverdrup $(2012,2014)$ found that horizontal contracts, and especially tight and relational contracts among colleagues in teams, influenced trust, collaborations, and friendship. These relations are important to people, and naturally one might fear violating the contracts. Examples from the narrative demonstrate that there probably existed both transactional and relational contracts among members of the top-executive team and among board members. Fear of losing friendships, together with close relationships in business networks, might have made colleagues hesitant to report; it might even have temporarily made them ethically blind, as discussed by Øverenget \& Storhaug Hole in Chapter 7. Unwritten agreements and expectations concerning mutual loyalty and trust among individuals on the board, in the leadership group, in the Ministry of Culture, and among colleagues within NT, seem to have influenced both the development of the whistleblowing process and its outcomes. Throughout the process, we get the impression of a subdued company culture where people did not voice concerns or express opinions openly.

Correcting the wrongdoing in a reasonable amount of time constitutes whistleblowing effectiveness (Near \& Miceli, 1995; Trygstad, 2017). In NT's case, the whistleblowing process lasted for many years. True, the wrongdoing was eventually corrected, but not within a reasonable time, and the seemingly interminable process put a heavy strain on everyone involved.

When blowing the whistle, PJS violated normative psychological contracts established in the company and the top leadership group: the unwritten expectations of supporting one another and keeping silent about company affairs. Though the Auditor General ultimately documented irregularities, PJS nonetheless seemed to get little support from co-workers (Auditor General, 2008/2009). Despite documented evidence of wrongdoing, it seems like they didn't dare support the whistleblower openly. They might have feared that by supporting the whistleblower, they too would violate normative psychological contracts and run the risk of reprisals themselves, such as social ostracism and loss of benefits and friendship. PJS's perception of lack of support is common in whistleblower cases (Rehg et al., 2008). Retaliation need not be open to be effective. There are other, more subtle ways of punishing the whistleblower-silence, freezing out, wage intimations, and holding back information (Mesmer-Magnus \& Viswesvaran, 2005; Bjørkelo, Einarsen, Nielsen, \& Matthiesen, 2011; Bjørkelo, 2013; Rehg et al., 2008). 


\section{Concluding Remarks}

Our analysis of this whistleblowing case shows that psychological contracts came into play, influencing several critical stages of the process. The way psychological contracts among people in business networks influence decision-making processes and outcomes needs further investigation. Based on our analysis of critical incidents in this narrative, and with support of earlier research into psychological contracts, we find that violation, or fear of violation, of both horizontal and vertical contracts influenced outcomes of this whistleblowing process. Psychological contracts might hinder employees and leaders from stepping forward and reporting, affecting both their willingness to report as well as their perception of the seriousness of the wrongdoing. Further, psychological contracts influence both decision-making processes and managerial responses to whistleblowing throughout the process, and we argue that this strongly affected the whistleblowing in this case.

The outcomes of a whistleblowing process depend significantly on managerial responses and the organizational climate (Trygstad \& Ødegaard, 2016; Trygstad, Ødegaard, \& Svarstad, 2018; Near \& Miceli, 2016). According to Lewis et al. (2014), research on managerial responses to whistleblowing is still in its infancy, but there is a growing interest in them. Vandekerckhove, Brown, and Tsahuridu (2014) argue that managers must both listen to and support the whistleblower. If managers are one of the parties in a whistleblowing case, as here, more conflicts tend to arise, the process lasts longer, and some cases remain unsolved (Trygstad, 2017). In our analysis, we find that managerial responses negatively influenced the development of the case. We suggest that psychological contract theory helps explain these research results and why the whistleblowing effectiveness was affected negatively.

\section{References}

Annual Report Norwegian Lottery 2017. Retrieved from http://2017.norsktipping.no/en/

Bjørkelo, B. (2013). Workplace bullying after whistleblowing: Future research and implications. Journal of Managerial Psychology, 28(3), 306-323.

Bjørkelo, B., Einarsen, S., Nielsen, M. B., \& Matthiesen, S. B. (2011). Silence is golden? Characteristics and experiences of self-reported whistleblowers. European Journal of Work and Organizational Psychology, 20(2), 206-238.

Bordia, P., Restubog, S. L. D., \& Tang, R. L. (2008). When employees strike back: Investigating mediating mechanisms between psychological contract breach and workplace deviance. Journal of Applied psychology, 93(5), 1104-1117.

Dozier, J. B., \& Miceli, M. P. (1985). Potential predictors of whistle-blowing: A prosocial behavior perspective. Academy of Management Review, 10(4), 823-836. 
Frøstrup, A. C. et al. (2018). Varslinger: verdier og vern. Varslingsutvalgets utredning om varsling $i$ arbeidslivet (NOU 2018:6). Oslo: The Department.

Greenberger, D. B., Miceli, M. P., \& Cohen, D. J. (1987). Oppositionists and group norms: The reciprocal influence of whistle-blowers and co-workers. Journal of Business Ethics, 6(7), 527-542.

Gundlach, M. J., Martinko, M. J., \& Douglas, S. C. (2008). A new approach to examining whistle-blowing: The influence of cognitions and anger. S.A.M. Advanced Management Journal, 73(4), 40-50.

Jensen, J., Opland, R., \& Ryan, A. (2010). Psychological contracts and counterproductive work behaviors: Employee responses to transactional and relational breach. Journal of Business \& Psychology, 25(4), 555-568.

Lewis, D. (2011). Whistleblowing in a changing legal climate: Is it time to revisit our approach to trust and loyalty at the workplace? Business Ethics: A European Review, 20(1), 71-87.

Lewis, D., Brown, A. J., \& Moberly, R. (2014). Whistleblowing, its importance and the state of the research. In Brown et al. (Eds.), International handbook on whistleblowing research. Cheltenham, UK and Northampton, MA: Edward Elgar Publishing.

Mesmer-Magnus, J. R., \& Viswesvaran, C. (2005). Whistleblowing in organizations: An examination of correlates of whistleblowing intentions, actions, and retaliation. Journal of Business Ethics, 62(3), 277-297.

Miceli, M. P., Dreyfus, S., \& Near, J. P. (2014). Outsider whistleblowers: Conceptualizing and distinguishing "bell-ringing” behavior. In Brown, A. J., Lewis, D., Moberly, R., \& Vandekerckhove, W. (Eds.), International handbook on whistleblowing research (pp. 71-94). Cheltenham, UK and Northampton, MA: Edward Elgar Publishing.

Miceli, M. P., \& Near, J. P. (2013). Some implications of the voice literature for research on whistle-blowing. In Voice and whistleblowing in organizations: Overcoming fear, fostering courage and unleashing candour (pp. 182-202). Cheltenham, UK and Northampton, MA: Edward Elgar Publishing.

Miceli, M. P., Near, J. P., \& Dworkin, T. M. (2008). Whistle-blowing in organizations. New York: Tylor Francis.

Miceli, M. P., Near, J. P., Rehg, M. T., \& Van Scotter, J. R. (2012). Predicting employee reactions to perceived organizational wrongdoing: Demoralization, justice, proactive personality, and whistle-blowing. Human Relations, 65(8), 923-954.

Miethe, T. D. (1999). Whistleblowing at work: Tough choices in exposing fraud, waste, and abuse on the job. Boulder, CO: Westview Press.

Morrison, E. W., \& Robinson, S. L. (1997). When employees feel betrayed: A model of how psychological contract violation develops. The Academy of Management Review, 22(1), 226-256.

Near, J. P., \& Miceli, M. P. (1985). Organizational dissidence: The case of whistleblowing. Journal of Business Ethics, 4(1), 1-16.

Near, J. P., \& Miceli, M. P. (1995). Effective-whistle blowing. Academy of management review, 20(3), 679-708.

Near, J. P., \& Miceli, M. P. (2016). After the wrongdoing: What managers should know about whistleblowing. Business Horizons, 59(1), 105-114.

Near, J. P., Rehg, M. T., Van Scotter, J. R., \& Miceli, M. P. (2004). Does type of wrongdoing affect the whistle-blowing process? Business Ethics Quarterly, 14(2), 219-242. 
NOU 2018:6. Varsling og vern. Official Norwegian Report on Whistleblowing. Retrieved from www.regjeringen.no/no/dokumenter/nou-2018-6/id2593665/

Olsen, J. (2014). Reporting versus inaction: How much is there, what explains the differences and what to measure. In International handbook on whistleblowing research. Cheltenham, UK and Northampton, MA: Edward Elgar Publishing.

Randall, D. M., \& Gibson, A. M. (1991). Ethical decision making in the medical profession: An application of the theory of planned behavior. Journal of Business Ethics, 10(2), 111-122.

Rehg, M. T., Miceli, M. P., Near, J. P., \& Van Scotter, J. R. (2008). Antecedents and outcomes of retaliation against whistleblowers: Gender differences and power relationships. Organization Science, 19(2), 221-240.

The report from Auditor General 2008/2009 (Document 3:14 (2008-2009)).

Restubog, S. L. D., Bordia, P., \& Tang, R. L. (2007). Behavioural outcomes of psychological contract breach in a non-western culture: The moderating role of equity sensitivity. British Journal of Management, 18(4), 376-386. https://doi. org/10.1111/j.1467-8551.2007.00531.x

Robinson, S. L., \& Rousseau, D. M. (1994). Violating the psychological contract: Not the exception but the norm. Journal of Organizational Behavior, 15(3), 245-259.

Rousseau, D. M. (1995). Psychological contracts in organizations: Understanding written and unwritten agreements. Thousand Oaks, CA: Sage Publications.

Rousseau, D. M. (1989). Psychological and implied contracts in organizations. Employee Responsibilities and Rights Journal, 2(2), 121-139.

Rousseau, D. M. (1990). New hire perceptions of their own and their employer's obligations: A study of psychological contracts. Journal of Organizational Behavior, 11(5), 389-400.

Rousseau, D. M. (2004). Psychological contracts in the workplace. Understanding the ties that motivate. Academy of Management Executive, 18(1), 120-127.

Rousseau, D. M., \& Tijoriwala, S. A. (1998). Assessing psychological contracts: Issues, alternatives and measures. Journal of Organizational Behavior, 19, 679-695.

Seeck, H., \& Parzefall, M. R. (2008). Employee agency: Challenges and opportunities for psychological contract theory. Personnel Review, 37(5), 473-489.

Skivenes, M., \& Trygstad, S. (2010). When whistle-blowing works: The Norwegian case. Human Relations, 63, 1071-1097.

Skivenes, M., \& Trygstad, S. (2014). Wrongdoing: Definitions, identification and categorizations. In Brown, A. J., Lewis, D., Moberly, R., \& Vandekerckhove, W. (Eds.), International handbook on whistleblowing research. Cheltenham, UK and Northampton, MA: Edward Elgar Publishing.

Sverdrup, T. E. (2012). The strength of reciprocity: Exploring horizontal psychological contracts in work groups. PhD-dissertation. Bergen: NHH Norwegian School of Economics.

Sverdrup, T. E. (2014). Psykologiske kontrakter i team. Beta, 28(2).

Sverdrup, T. E., \& Schei, V. (2015). "Cut me some slack”: The psychological contracts as a foundation for understanding team charters. Journal of Applied Behavioral Science, 51(4), 451-478.

Thompson, J. A., \& Bunderson, J. S. (2003). Violations of principle: Ideological currency in the psychological contract. Academy of Management Review, 28(4), 571-586. 
Trevino, L. K., \& Victor, B. (1992). PJS reporting of unethical behavior: A social context perspective. Academy of Management Journal, 35(1), 38-64.

Trygstad, S. C. (2017). Kunnskapsstatus og varsling og varslingsprosesser. Oslo: FAFO-notat.

Trygstad, S. C., \& Ødegaard, A. M. (2016). Whistleblowing and freedom of speech in Norwegian working life 2016. English summary of Varsling og ytringsfrihet i norsk arbeidsliv 2016. FAFO-rapport 2016:33.

Trygstad, S. C., Ødegaard, A. M., \& Svarstad, E. (2018). Varslingsrutiner på arbeidsplassen som redskap for åpenhet og trygghet. (Whistleblowing routines as management tools for openness and safety). Magma, 03-2018, 48-56.

Turnley, W. H., \& Feldman, D. C. (1999). The impact of psychological contract violations on exit, voice, loyalty, and neglect. Human Relations, 52(7), 895-922.

Vandekerckhove, W., Brown, A., \& Tsahuridu, E. (2014). Managerial responsiveness to whistleblowing. Expanding the research horizon. In Brown, A. J., Lewis, D., Moberly, R., \& Vandekerckhove, W. (Eds.), International handbook on whistleblowing research. Cheltenham, UK and Northampton, MA: Edward Elgar Publishing.

Vandekerckhove, W., \& Commers, M. R. (2004). Whistle blowing and rational loyalty. Journal of Business Ethics, 53(1-2), 225-233.

Vantilborgh, T., Bidee, J., Pepermans, R., Willems, J., Huybrechts, G., \& Jegers, M. (2014). Effects of ideological and relational psychological contract breach and fulfilment on volunteers' work effort. European Journal of Work \& Organizational Psychology, 23(2), 217-230.

Zhao, H. A. O., Wayne, S. J., Glibkowski, B. C., \& Bravo, J. (2007). The impact of psychological contract breach on work-related outcomes: A meta-analysis. Personnel Psychology, 60(3), 647-680. 